\title{
What is learning for secondary-school students? Students' perceptions examined in Brazil and Finland
}

\author{
Juliene Madureira Ferreira $^{1}$ (D) Tiina Soini $^{1} \cdot$ Reijo Kupiainen $^{1,2}$. \\ Ana Claudia Salum ${ }^{3}$
}

Received: 6 June 2018 / Accepted: 30 January 2019 / Published online: 5 March 2019

(c) The Author(s) 2019

\begin{abstract}
In the present study, learning in school was studied from the students' perspectives in two different national contexts. The aim was to explore students' learning experiences in school by identifying what are the core elements of learning for secondary school students. We conducted the study with a qualitative approach in which photos taken by the students during their school routines were used to elicit group discussion about how learning is experienced and defined. Participants were two groups of 13-15-year-old students, one from Finland and one from Brazil. Results show that the anatomy of learning is varied in students' experiences and that their perceptions of learning in school are defined by the way students signify the interaction with others, their relation with materials, their understanding of the pedagogical actions and practices, and how learning is contextualized by time. The study contributes to discussions on how to consider and incorporate students' perspectives into the development of pedagogical practices, and by the dialogue between Finnish and Brazilian perspectives, we point out core elements for the learning experiences of secondary school students raising questions of learning processes as complex and culturally contextualized.
\end{abstract}

Keywords Students' perceptions · Learning experiences · Secondary school · Multicultural research

\section{Introduction}

One of the greatest challenges in education is to develop practices that address the learning needs of the current generation of students (Schoenfeld 1999; Schleicher 2012). Thus, learning processes continuously are under review. A possible way to improve educational practices and environments is to understand how students

Juliene Madureira Ferreira

Juliene.madureiraferreira@tuni.fi

Extended author information available on the last page of the article 
perceive them, make sense of them and value different aspects of the learning process.

de Lima et al. (2015) have asserted that analyzing learning experiences through students' perceptions allows researchers to construct understandings that synthesize sensibility (the lived act) and reason (the discursive system that describes and attributes meaning to the world). Through students' perceptions, it is possible to address learning concepts that, according to Cano and Cardelle-Elawar (2004), entail individual constructions that develop from knowledge and experience, defining different ways in which learning is understood. Learning concepts can be characterized by what students understand about pedagogical strategies, tasks or other activities, and objectives (Vermunt and Vermetten 2004), and can reveal how schooling is integrated as a lived experience that makes a significant impact on learning outcomes (Tsai 2009).

Lately, students' perceptions have been studied from diverse perspectives, such as in the investigation of behavioral mechanisms of effort allocation (Hiemstra et al. 2018), in which findings indicate positive correlations between effort allocation and self-directed instructional pedagogical strategies. It appears in studies that aim to assess specific tools, such as interactive whiteboards (Niekerk 2015) and innovative learning environments (Magen-Nagar and Steinberger 2017; Schenke et al. 2017), and through investigations of student-teacher relationships (Gasser et al. 2018; Quin et al. 2017). Discussions raised in such studies support the idea that focusing on students' experiences is another way of thinking about education, shedding light on the importance of listening to those who not only are part of, but also construct, the learning process (Gallo 2014).

In addition to recognizing the value of addressing students' perceptions in a variety of ways, recent studies also argue that children have the right to be heard and to participate in the processes that define their lives (cf. Hanson 2012). In this sense, it is understood that children's perspectives are equally important as those of adults, and we believe that by addressing students' perceptions, it is possible to determine significant elements and understand how this new generation of students constructs meaning from their learning processes in a more holistic approach. Instead of focusing on predetermined topics, such as specific tools or teacher-student relationships, we find it essential to explore the elements that students identify as central to defining the process of learning. In this sense, we investigated learning from students' perspective, aiming to grasp their understanding of when and how learning experiences happen. As such, we raised the following research questions:

- What elements characterize learning in students' perceptions during their experiences at school?

- Are there differences in the way students from distinct social contexts perceive learning? What kind of differences exist in Brazilian and Finnish students' perceptions of school as a learning environment?

- What kinds of similarities can be understood as core elements of the learning experience? 


\section{Learning as meaning-making}

Our understanding of learning is based on the social-historical perspective (Vygotsky 1991; Valsiner 2000; Wallon 1981, 1986), which embraces a systemic character of social relationships that, by adopting a notion of complexity (Morin 1990), emphasizes interactions with others as being central to the human constitution. Within this perspective, learning happens fundamentally through interactions with the context-circumscribed by culture, afforded by physical features, and defined particularly by relationships with other people. Learning is an interpersonal process that inextricably conducts human development (Newman and Holzman 1993). Thus, it is not only about acquisition of systematized knowledge and skills, but also an ongoing, interactive process of meaning-making and development in which motives and emotions play an important part (Lasky 2005; Lonka et al. 2000; Nonaka and Nishiguchi 2001; Paavola and Hakkarainen 2005; Wenger 1998; Wertsch et al. 1993).

For the past decade, research on students' perceptions has emphasized the meaning-making process as a central element for learning, highlighting students' active participation in negotiating places and roles, and constructing culture (Greeno 1997; Resnick 1991; Salomon and Perkins 1998; Sfard 1998). Findings from such studies support the claim that the ways in which students relate to knowledge and the school environment, perceive learning, and recognize themselves as learners are mediated by cultural processes of meaning construction, produced through representation systems and affordances, creating potentials for meaning-making processes in each context (Bezmer and Kress 2016). Thus, even being explicitly a collective process, learning is experienced individually and should be considered within the complexity that is characteristic of subjectivity (Larrosa 2002).

When focusing on students' perceptions of learning, studies have pointed to different defining elements related to such processes. An extensive body of extant research examines the importance of teacher-student relations. Students who consider their teachers to be caring are likely to internalize pro-social goals at school (Wentzel 1999), and this correlation improves students' engagement in academic activities (Anderson et al. 2004; Furrer and Skinner 2003; Klem and Connell 2004; Lee 2012; Patrick et al. 2007). More recently, Quin et al. (2017) found positive associations between teaching quality and better behavioral and emotional engagement among students, reaffirming the view that despite not having an exclusive role in influencing students' engagement, quality teaching plays an important part. In the same way, different studies from students' perspectives indicate a similar significance from peer-to-peer relations (Boulton et al. 2011; Martin and Dowson 2009). Notably, peer relations can be associated with conflicting situations, either prompting students' engagement in learning environments (Furrer and Skinner 2003) or vice versa, indicating that peer relations also can challenge students' emotional engagement with schoolwork (Ulmanen et al. 2014). From a general perspective, it is possible to affirm from all these findings that learning takes place "in a participation framework" (Hanks 1991, 13) in which the presence and actions of other people design the learning environment and set the bases for their experiences. 
Additionally, the way that students perceive learning environments also can play a significant role in prompting their engagement in learning processes. Recent studies have shown that educational-institution climate impacts academic outcomes (Farley 2002; Gloria and Ho 2003), and that students perceive various digital tools applied in school classrooms, such as the Internet, as resources that support their studies, although they do not transform how learning takes place (Domingo and Garganté 2016; Henderson et al. 2017). Learning environments and schools also can be understood as places in a socio-spatial sense, i.e., spaces and sites in which to engage students who are, simultaneously, members of multiple communities (Comber 2016). The foundation of such spaces is social. Students make spaces with their peers and teachers. Socio-cultural perspectives in learning environments and school spaces emphasize that spaces are not fixed or naturally provided, but contingent, changeable, and possible for negotiating something new and better through collective actions and human interrelations (Massey 2010; Soja 2011; Kupiainen 2013; Comber 2016). Furthermore, such spaces are constituted in different relations in which teaching and learning take place.

The affordances and restrictions of the learning environment, and experienced relationships with each context, may lead to learning that is not facilitating growth and fulfilling human potential. Moreover, social roles are performed in different contexts and in the presence of different people. The same person can perform different roles in different social relationships in different contexts. More than cognition, we focus on participant-situated activities and socio-cultural practices in students' learning environments and how they describe their activities while learning within specific learning environments.

Despite the relevance of the aforementioned extant studies, in which predetermined definitions of learning are investigated from specific process perspectives, we still consider it important to investigate how students understand learning, define learning, and identify it within their experiences in school. Thus, we investigated the elements that were important to students in defining the learning process. Moreover, although it is recognized that learning happens in a variety of spaces and situations, the school is a central developmental context for children and adolescents-a social, cultural, psychological, and multilevel learning environment and a complex context with multiple levels and practices (Pyhältö et al. 2010). As a dynamic and complex context, it provides a range of opportunities, challenges, and demands for students, e.g., performing academic tasks, forming friendships, maintaining group memberships, and resolving possible conflicts (Eccles and Roeser 2011). The ways in which students engage in the academic and social processes of school and make meaning out of them will define their learning paths.

It is important to consider that schools' pedagogical processes are an intentional intervention into the ongoing flow of learning, with very specific goals. Moreover, learning in school usually is organized with the logic of content manifested in subjects. However, students' learning at school does not always, or hardly ever, follow the intended route. Students learn all the time, in different places, but the content of learning in these various contexts may be surprisingly different from the learning goals that teachers plan because the process of meaning-making is mediated through culture and students' own intentions, affected by, for example, the 
quality of interactions between teachers and students. Thus, the pedagogical processes within school communities might either hinder or promote meaningful learning (Hakkarainen et al. 2004; Krapp 2005). The cultural methods of organizing the school context provide subjects with methods of relating and representing knowledge. Therefore, analyzing students' perceptions, through discursive practices, can facilitate understanding of the ways in which they relate to learning in school, giving meaning to learning and even producing it. Based on our understanding, defining a good or suitable learning environment for all is impossible. Instead, when seeking high-quality learning environments, we should try to understand the ways in which students experience, interpret, and intend to construct learning environments around them.

To understand how students construct relationships with learning and with school spaces, it is necessary to consider their social positions and the cultural aspects in which these adolescents already are immersed. Cultural constraints can shape students' perceptions, implying specific ways to symbolize and classify the world/reality that are central to the production of meaning and reproduction of social relations (Woodward 2003). In this particular study, we developed a cross-cultural dialogical approach that supported the methodology to investigate core elements of students' perceptions of learning, considering some level of comparison between two different social realities. According to Cowen (2000), "reading the world" (p. 334) is the most important aspect of comparison in research, i.e., it is only by exploring the complexity contained in the local level and critically interrogating the nature of divergence and difference that a substantial perspective can be constructed for interpreting global educational processes, and by placing different realities into the mix, it is possible to identify elements that, without contrast, would not appear.

The main purpose behind adopting such a perspective is to know the other, understand the other, and reflect on specific aspects of what learning means, and how secondary-school students identify it. For this purpose, we chose two distinct social realities as research sites, Brazilian and Finnish. This choice is not merrily based on the convenience of having strong academic collaboration between researchers from both countries but is grounded on previous multicultural studies between Finland and Brazil (Rutanen et al. 2013; Rutanen et al. 2016; Ferreira et al. 2018) that have revealed interesting contributions from both nations, indicating that such cultural, social, and economic differences can provide a rich context for investigating educational matters.

\subsection{Short overview of the organization of Brazil and Finland's educational systems}

The organizing principles of the educational systems and the cultural features of each society shape and define the learning environments and processes in the micro level of a classroom, determining the experience of learning and how students make meaning of such process. In this study, the most relevant elements in which to contextualize the Brazilian and Finnish education systems are related to: 
(1) implementation of a core curriculum; (2) development of ideals on equality and equity; and (3) use of standardized testing to steer educational outcomes.

For over four decades, the National Core Curriculum has steered the Finnish educational system. As a state political entity, it sustains the idea of equality as the main strategy of the welfare state, which characterizes the history of curricular thinking and the goals of education in Finland (cf. Sahlberg 2011a, b; Simola 2005). It also supports the development of a completely publicly funded education system, including daily school meals and health services, resulting in equal opportunities for individual growth and a homogeneous educational path. Additionally, there are no ability-tracking structures or educational barriers separating comprehensive school students from pursuing academic or vocational education, and there are flexible accountability structures that place a strong emphasis on trusting schools (Aho et al. 2006).

On the other hand, the Brazilian educational system only recently started implementing its version of the National Core Curriculum. Previously, the Ministry of Education and the National Council of Education defined guiding principles for all levels of education, with schools having had the prerogative to design their curricula according to local contexts and budgets. This situation contributed to inequality, considering the country's history and socio-geographical constraints (Arias et al. 2004). Additionally, the public system does not meet the country's demand, with significant gaps (at all levels) that are supported either through the private sector or areas and populations that are not properly assisted (Azevedo and Santos 2012). To address such an unequal system, standardized quality assessment in education has played a role in steering implementation of education policies or programs (Kauko et al. 2016). Contrary to Finland, national testing systems are used for each level of education, and during the past decade, Brazil has joined international large-scale assessment processes, utilizing the results to implement different educational policies (Shiroma and Schneider 2012).

Considering these distinctions it would be expected that students from both nations experience schooling very differently (and diversely). However, we understand that the contrast between these two social realities is an opportunity to identify core elements present in students' perceptions about learning, which reveals then frameworks for understanding learning experiences. To establish grounds for common analysis, we carefully chose two schools to participate in this study that could offer the same 9-year comprehensive education, with 200 school days annually and an average of four-and-a-half hours of study daily. Both schools are teacher-training schools that are part of public universities, and besides English, both offer two additional foreign-language courses, as well as an extensive art curriculum.

\section{Method}

Considering the objectives of the present study, we chose to pursue investigative procedures through a qualitative approach, structured and guided by a constructiveinterpretative process connected to culture and social history (González-Rey 2002). The constructive-interpretative perspective considers researchers' subjectivity as an 
essential element in constructing hypothetical indicators that will guide construction of the corpus and its analysis. The method is not predetermined, but rather active and dialectic, allowing for interpretation of data that can lead to new processes of collection and analysis (González-Rey and Mitjánz 2015).

\subsection{Research sites and participants}

In Brazil, the site for research was the Application School of the Federal University of Uberlândia, a special unit that supports that university's pre-service teacher training. From this institution, ten 13- to 15-year-old Brazilian eighth-grade students participated in this study. In Finland, the site for research was the Teacher Training School of the Faculty of Education of the University of Tampere, which is characterized as a research and learning community, responsible for all teacher training at that university. From the Finnish context, fifteen 14- and 15-year-old ninth-grade students participated in the study.

To select the participants, we applied three criteria: students' consent to participate in the study, their parents' acceptance of all processes and understanding of ethical issues involved with their children's participation, and all participants' engagement in data-collection procedures. Participants who missed any data-collection sessions were dismissed from the data set. Ethical measures, e.g., filters to prevent face recognition in pictures and anonymous coding to prevent identification of participants' narratives, were adopted to preserve participants' anonymity, as promised in the official authorization statement that all parents signed.

\subsection{Data collection: resources and process}

Data collection was carried out initially using one two-step protocol for both countries. The first step entailed constructing materials that allowed children to represent learning situations and the connections established by them among learning, knowledge, and school contexts. Data were constructed during a group-discussion session and an individual reflective task consisting of photographing situations, spaces, and/or objects that students felt represented their learning processes, schooling, or specific knowledge (for further methodological reference in the use of photography to represent individuals' qualities, see Telles 2006, 2007). Previous studies in education research (cf. Clark 2005; Cook and Hess 2007; Einarsdottir 2005; Harcourt and Mazzoni 2012) reported benefits from exploring children's representations through photography, enabling them to present their views through a communication medium other than textual language.

The instructions for the individual task were the following:

We ask you to register moments (scenes or spaces) of your schooling life in which you feel (think, understand, or have a perception) that you are learning. When taking pictures, please, think about what is happening in that moment and why you are taking the picture. You can take notes of your thoughts if you wish, but it is important that you reflect about what you are registering. 
The students were allowed to use school cameras or their own cell-phone cameras for this task and circulate throughout their school with camera devices for 2 days. Teachers and other students were notified about the assignment, and ethical issues, such as asking for permission to take pictures (cf. Allen 2012), were discussed with participants beforehand.

The second step in data collection entailed constructing material to analyze meanings that students constructed collectively about their learning processes. For that, we held one group-interview session (approximately $50 \mathrm{~min}$ long) and used the photos taken during the previous step to elicit students' reflections and guide the discussion (cf. Harper 2002). The pictures taken by students were presented randomly through a simple PowerPoint presentation during the group-discussion session. To prompt the discussion, we also administered a questionnaire containing the following questions: What is happening in this picture? What were you thinking or feeling when you took this picture? Why did you take this picture? What is happening here that interests you? What were you learning in this moment? In which situations do you learn? Where do you learn? What do you learn in school? With/from whom do you learn? How are they involved? Do you think you are learning right now?

It is important to mention that in Brazil, there was not enough time to present all the pictures taken ( 23 out of 44 were presented), but all the students in the study had at least two of their pictures displayed, while their peers provided input on them. In Finland, there was enough time to present and discuss all 26 pictures taken. In both contexts, the group interview was video-recorded. All dialogues were transcribed word-to-word based on the videos. Notes contextualizing the content of the dialogues were added to the side of the text. Following, the entire material was professionally translated into English, and then double checked by native speakers in Portuguese and Finnish with professional fluency in English, generating material for analysis. In Brazil, the data were collected in December 2015, and in Finland in April 2016.

\subsection{Data analysis}

The data-collection process generated two forms of data: students' pictures and transcripts of students' discussions about each other's pictures. In this study, we prioritized the analysis of students' discussions and analyzed the pictures only based on surface meaning cited, using the content of each picture to register students' representations of their learning experiences, i.e., no artistic interpretations (cf. Thinker 2013) were applied, and the pictures were used as complementary data that supported analysis of the meaning-making processes registered through students' discourses. Four types of content emerged from the initial analysis of the pictures. The first is objects, in which the picture's focus is on one specific object, such as a book, computer screen, tennis racket, etc.). The second category is specific places, with the camera used to capture an entire room, such as a laboratory, cafeteria, or classroom. The third category is people, in which students used other students, teachers, and others as central elements in their photos. Notably in this category, people posed for the camera when they were made aware of it. The fourth and final category is 
scene, which is a combination of elements suggesting an actionlsituation. In this category, you may find a photo of students performing a task (e.g., a lab experiment) or moments related to classroom routines (e.g., a teacher instructing by using the contents on a white board). In this category, people are not aware of the recording and are not posing for the pictures. Unlike the people category, the understanding here is that the action is the central element-not the people engaged in the action.

For the material gathered during the photo/image-elicitation group interview, we applied a content analysis (cf. Kondracki et al. 2002) on transcripts from both data sets. For such analyses, the material was prepared through: (1) transcription and translation of the interview-dialogue transcripts from their original languages (Brazil/Portuguese and Finland/Finnish) into English, and (2) language adjustment and proofreading.

The initial procedure of coding entailed organizing pictures according to the sequence of dialogues, based on the research questions what, where, how and from/ with whom students learn. For such, we identified in the students' dialogue the units of analysis, which would answer these questions. This coding process was submitted for: (1) local coding (a Brazilian researcher coded the Brazilian data, and a Finnish researcher coded the Finnish data); (2) international blind coding (a Brazilian researcher coded the Finnish data and vice versa); and (3) joint analysis of both sets of material (involving all researchers in both countries) to develop a method for juxtaposition of multicultural data. In this third process, we analyzed divergent results and incorporated translations of cultural elements that were essential to contextualizing and understanding each data set.

In a subsequent content analysis, we considered words or phrases that built an idea as content components, and we focused on analyzing latent meanings in the discussions constructed through student interactions to identify analysis categories. Therefore, we did not consider individual ideas separately, but rather the social subjectivity expressed by shared reflections. To illustrate, we present an excerpt of the analysis in Fig. 1.

\begin{tabular}{|c|c|c|c|}
\hline Interview transcript & $\begin{array}{l}\text { Relevant content } \\
\text { component }\end{array}$ & Meaning interpretation & $\begin{array}{l}\text { Category of } \\
\text { analysis }\end{array}$ \\
\hline $\begin{array}{l}\text { We had a French class and we were } \\
\text { studying the lyrics of a song and then we, } \\
\text { there was a puzzle where you had to } \\
\text { combine the words into French and Finnish } \\
\text { and, I took the photo because it was a kind } \\
\text { of a different learning situation you don't } \\
\text { have too often in Math class, for example. } \\
\text { When you don't do puzzles or the like. And it } \\
\text { was like, it was like a really relaxed } \\
\text { atmosphere and... yeah. }\end{array}$ & $\begin{array}{l}\text { "a kind of a different } \\
\text { learning situation" } \\
\text { "in Math class, for } \\
\text { example. When you } \\
\text { don't do puzzles or the } \\
\text { like." } \\
\text { "it was like a really } \\
\text { relaxed atmosphere" }\end{array}$ & $\begin{array}{l}\text {-Recognizing different } \\
\text { learning situations } \\
\text {-Not doing puzzles in math } \\
\text { classes } \\
\text {-Doing puzzles being } \\
\text { creating relaxed } \\
\text { atmosphere } \\
\text {-Being possible to learn in } \\
\text { relaxing atmospheres } \\
\text {-French class creating } \\
\text { relaxed atmosphere }\end{array}$ & $\begin{array}{l}\text { Action } \mid \\
\text { Practices }\end{array}$ \\
\hline
\end{tabular}

Fig. 1 Example of content analysis. This figure ilustrates the procedures adopted for the discourse analysis of the group interviews with students 
The analysis of students' discourse resulted in four categories representing the elements/features of their learning experiences: (1) Interaction, which entailed descriptions of social surroundings and partners during learning situations; (2) Time, which comprises references to the past, present, or future in students' learning perspectives; (3) Material, including books and equipment; and (4) Actions, which consisted of descriptions of practices and actions.

\section{Results}

The initial set of results comes from analysis of the surface meaning of students' pictures. The results revealed that students chose to represent learning mainly by registering four types of content: objects, places, people, and scenes. The frequency of these specific elements are made explicit in Fig. 2.

Results show differences between the ways that Brazilian and Finnish students pictorially presented their learning situations. While the Finnish students constructed their representations mainly by framing objects (e.g., books, rackets, personal belongings, and materials used during class), Brazilian students used pictures of scenes containing combinations of different elements in their pictures. Generally, representations of learning by using pictures of objects could suggest an idea of learning as being a content-related, book-based phenomenon, or that students developed such a focus during the assignment. On the other hand, the representation of learning through pictures of compositions of elements, which in this study were called scenes, could suggest an idea of learning as a process or an action. Interestingly, peers were one of the central elements used by Brazilians to compose their scene pictures. This set of results led to reflections on participants' representation profiles, raising the first question about students' understanding and construction of representations of learning in school.

The subsequent set of results originated from the content analysis based on the identification of what, how, where, and from/with whom the learning happens. From a general perspective, when Finnish students specified what they were learning, they

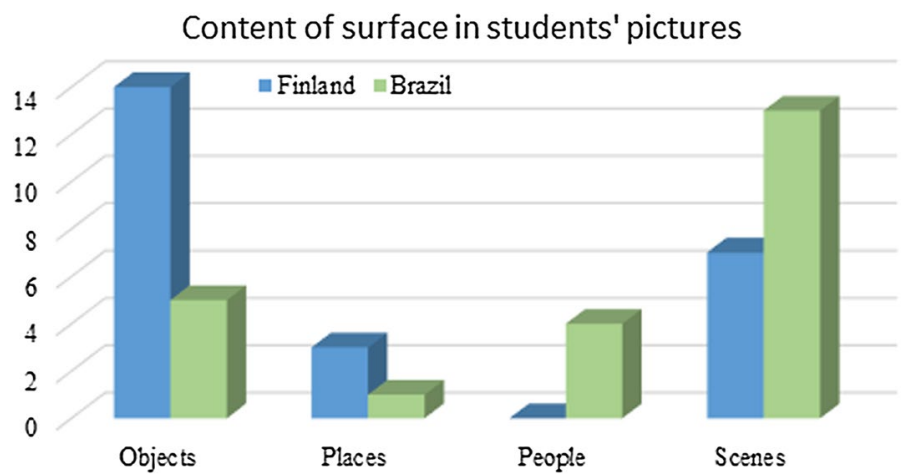

Fig. 2 Contents of surface in students' pictures. The figure explicits the pictorial representation of learning when we analyse the content of the pictures 
expressed themselves using content directly related to the academic curriculum (e.g., learning pronouns, learning angle calculations, etc.). The location where these learning situations occurred was mentioned spontaneously in most discourses (24 out of 26), indicating that learning for this group of students is identified more intensively (22 out of 26) inside school spaces, especially in classrooms during different classes, e.g., Mother Tongue, Gymnastics, Math, Home Economics, and French Language. The expression of how learning happened was identified only 12 times during the analysis of students' discourse. The content related to this specific element varied significantly, at times showing more practical and didactic references "combining the words together" (Student A, Finland, referring to how he learned the lyrics of a song in French), and at times approaching a broader explanation of how learning happened: "We were listening to all different sounds" (Student D, Finland, referring to learning to play the guitar in music class). Finally, when Finnish students talked about with whom they learned, which only happened during discussions of eight out of 26 pictures, they mentioned their peers five times and explicitly associated their learning experiences with an individual and independent work three times.

The same analysis in the Brazilian data set revealed a different perception of learning. For Brazilian students, the content of learning (the what) appeared only when discussing 16 out of the 23 pictures and mostly was related to learning to perform socially demanded actions (e.g., chatting with a friend, fraternizing with the group, participating collectively, and creating harmony). Interestingly, it was only when discussing the pictures from history class and from the science lab that students revealed a connection to academic content (e.g., history of Brazil, DNA experiments, or the French Revolution). The same happened regarding their expression of how and where learning happens, with results revealing that it was only during these two specific learning situations when the process of how learning occurs was clear enough to be expressed spontaneously. In the case of the science lab, learning happened through practical work, constructed in groups and assisted by the teacher. During history lessons, learning happened through co-construction of formal knowledge. The teacher and students interacted during lectures to make the class "funny and relaxed" (Student B, Brazil, referring to how the history teacher behaves in class). However, unlike the Finnish results, Brazilian students mentioned a variety of places where they said learning happened (e.g., cafeteria, yard outside the school, and the entrance hall) and noted how peers and teachers played significant roles in learning at school. Peers were mentioned during the discussion of 11 out of 23 pictures, and even when peers were not mentioned explicitly in students' discourse, they somehow were represented in the pictures. Teachers appeared less frequently (only six times), but occupied a position of influence: "You like the teacher, you like the lesson, it becomes different" (Student F, Brazil, referring to a science teacher).

This second set of results allowed us to map out important references concerning how students understand the learning process. The content analysis amplified the meanings constructed initially by analysis of the pictures, either revealing new elements or reaffirming content explicit in the pictures.

The final content-analysis procedure entailed interpreting meaning from relevant content components. The results of this final analytical process revealed four distinct categories that explained key Brazilian and Finnish learning experiences: actions/ 
practices, materials, interactions with others, and time (see Fig. 3). In the next section, we will present the results according to each category, exemplifying children's perceptions with excerpts from the original data sets.

\subsection{Materials}

This category assembles a set of expressions of how students relate learning to material things. Materials are interpreted here as everything that exists as objects or places and are used, constructed, or understood as part of students' learning experiences. The association between learning and materials was present equally in the results from both data sets, and through this category, we identified two relevant ideas: First, from students' perspectives, learning is supported through the use of objects (e.g., books, lab equipment, sports equipment, computers, etc.), and second, both groups of participants held distinct value perspectives concerning material things.

Regarding the first main idea, this material support appeared in the discourse of both groups, either in situations of individual activities, such as in individual assignments with a book during recess, e.g., "I do some bonus assignments, and it helps with my learning" (Student B, Finland, referring to the exercise in the book), or in group assignments developing guided experiments, e.g., "Making a DNA experiment, it is a situation where you do something different from what you do in daily life, inside the classroom" (Student C, Brazil, referring to science equipment used during lessons in the science lab). This support for learning also was indicated by students' explanations of how different teachers' use of materials provided distinct learning experiences. For example, for Finnish participants, the use of a specific game during French class provided the sensation of a relaxed way of learning:

It is a kind of different learning situation (French class) ... it was like a really relaxed atmosphere (Student A, Finland, referring to a comparison between French and Mathematics classes).

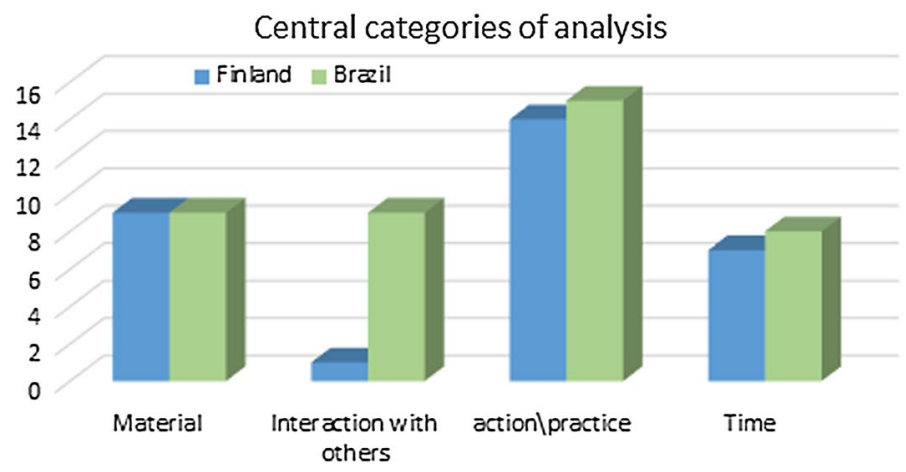

Fig. 3 Central categories of analysis. Figure shows the results from the interpretation of the meanings of relevant content components in students' discourses 
For the Brazilian students, the use of the whiteboard supported a methodology of teaching:

He constructs step by step on the board (Student A, Brazil, referring to how the teacher organizes the content on the board).

They (teachers) use the board to explain the content...And everything we need to learn (Student F, Brazil, also referring to the use of the whiteboard).

Similarly, this category also indicated how students identified different spaces as learning spaces. For Finnish participants, it was more common (19 out of 27) to recognize the classroom as a learning space, but there also were references to places outside school contexts, such as the Orthodox church visited by the group, or even to situations outside of school hours (e.g., during sports practice after school). Brazilian students didn't mention any particular place outside the school, but identified, as learning spaces, different places beyond the classroom. For this group of participants, the entrance hall of the school, the lawn at the end of the school campus, the cafeteria, and several classrooms were associated with learning situations: "Here it is when we go to another space (cafeteria) to interact with other classes, other grades, and I think it is important too. Ah, it is because we learn... how to interact with people..." (Student B, Brazil, referring to the description of a picture from the cafeteria during break time).

The second finding that this category revealed was that both groups of students distinctly valued material things. In between students' discourse, we found expressions that disclosed an attribution of value to material things that support learning situations. For Finnish students, learning can be related directly to the independent use of materials, positively valuing their relationship with resources such as books and exercise handouts:

Then, there was that (math book) in Math, when I calculated math about those ratios. So, it was quite nice (Student B, Finland, referring to an exercise book).

In contrast, Brazilian students-despite recognizing that books, exercise handouts, and other materials supporting their learning situations-expressed negative values related to this material, viewing them as boring or tiring activities:

It is a waste of time to do exercises (Student D, Brazil, referring to the exercise handout).

He (the teacher) not only copies something from the book or speaks something already memorized. He makes his own schemes (...). I think it is a much more interesting way to study (Student B, Brazil, referring to the picture of the whiteboard during the history class).

In this case, students explicitly expressed their preference for learning through mediation of the teacher's instructions, rather than through the guidance and structure offered by the book in independent work. 


\subsection{Interactions with others}

The category "Interactions with others" comprises students' perceptions of the active role of others (peers or teachers) during their learning situations. The analysis showed that both groups of participants acknowledge the presence of peers and teachers in their learning situations, and they recognize that group assignments are a common pedagogical structure, clearly indicating when collective or individual assignments are happening. However, this acknowledgement did not necessarily appear to be a relevant content component, i.e., mentioning the other is not a definer for the learning situation in student discourse. When analyzing relevant content components, we identified differences between the two groups of participants, not only regarding the frequency of this subject in their discourses, but also the quality of how students relate interactions with others to their learning situations.

On one hand, for the Brazilian group, references to others appeared in the discourse of nine different students, but on the other hand, for the Finnish group, this relation was found only once. The nature of this association between significant others and learning also was different in students' discourse. Learning to interact with peers and valuing emotional bonds with the teacher seemed to be the focus in Brazilians' discourse, which appeared to be directly related to how students feel within the school context, and at times was expressed as something that defined the learning experience. Brazilian students explicitly revealed that the affection toward their peers and teachers determined their motivation to be at school, as well as their emotional response toward the lessons and the process of knowledge construction:

It was a moment we were celebrating the teacher's birthday. This moment also means a kind of affection we have to the teachers, the same way they have to us, we want to give it back. I think it is a moment of fraternization among us, OK? (...) I think it is a moment when we start to learn to get to know each other, got it? (Student B, Brazil)

Well, I think a strong point is that the student has good ties with/in the school because if the student doesn't have any friends at school, no one, nothing that let him (feel) comfortable in the space, of course he won't be in this space. Then, I think this is something that attracts the student to school. He wants more and more to be in the space; it will be a pleasant space for him (Student

A, Brazil).

You like the teacher, you like the lesson (Student C, Brazil).

For the Finnish group of participants, despite mentioning the structure of the learning situation as being based on a group assignment, only one student expressed a direct relation between learning and interaction with others. In this case, the focus remained on being interested to learn more about something that was important to a particular friend:

(...) And then a friend of mine is Orthodox, so it was interesting, like, to hear everything that goes with it. So, it was nice to know more about (Orthodox religion) (Student D, Finland, referring to the picture of the trip to the Orthodox church). 
This difference in values opens up the possibility of exploring socio-cultural elements and their direct influence on schooling and learning in school.

\subsection{Action and practice}

The category 'Action and practice' comprises students' diverse perceptions of how learning can happen, or how it can be structured according to their learning experiences in school. Similarly, Finnish and Brazilian students associated learning with processes in motion, i.e., actions that take place in school:

We made water bagels, and like, I've never made them before, and so I learned that, how to make them (Student H, Finland, referring to the picture of a situation in a home-economics class).

It (the picture) explains the moment the teachers are talking. They (teachers) explain the activities, and we learn (Student G, Brazil, referring to the picture of a learning situation in class).

Participants also were equally explicit about how a practical aspect of the learning process is relevant for them:

It is much better when you do something practically than theoretically because we, as teenagers, we have to be proved in order for us to believe (Student D, Brazil, referring to science lessons in the lab).

We were in Technology class and made a robot like that... that won't get away. Well, it was pretty nice to do, though, when we programmed it ourselves (Student J, Finland, referring to a technology class).

These examples make it clear that for both groups of students, when they reflect on identifying learning situations, they do so through actions, or processes, that they or their teacher initiate. However, despite this similarity in how to associate learning to an action, we also find in this category that Finnish students provided direct and focused comments about how learning is identified while they are doing something, executing a task or constructing materials by themselves, as the excerpts below indicate:

I learned to make a robot that moves on red paper, and that's a photo of it, of programming (Student I, Finland).

I learned to do a smash stoke (Student E, Finland).

I learned, I did some assignments alone (Student B, Finland).

Conversely, for Brazilian students, expressions regarding action and practice also appeared in the form of criticism and evaluation, of which they value pedagogical practice more and disapprove of certain actions involving learning:

it is very tiring to stay writing all day long (Student F, Brazil).

I think it is because it is a waste of time if you stay doing exercises in the book because you are going to get tired and bored of studying. I think that the way he (teacher) explains, makes it easier to understand because he is speaking, he 
transmits knowledge for you, and you are not going to get tired of doing exercises in the book (Student K, Brazil).

In this particular case, it is possible to notice that there is a distinction regarding values or preferences related to teaching methods. The Finnish students didn't express such criticism, offering positive input about a pedagogy that privileges individual involvement and independent work in the classroom. This group of students expressed positive feelings and a perception that these pedagogical practices are effective for learning. Conversely, Brazilian students explicitly disapproved of independent work, especially involving exercises.

\subsection{Time}

This particular category refers to how students expressed the phenomenon of learning in relation to the notion of time. Within this category, two central meanings were revealed that are relevant for both groups of students: the association of learning with content or an experience that is new, and the understanding of content learned as something important that will be used in the future. These two central meanings appeared in students' discourse through very similar expressions, such as:

We are getting a new knowledge that will help us; it will help us in the future

(Student F, Brazil, referring to a picture of a scene in which the teacher is explaining new content).

It was the first time I welded. It was pretty exciting. It was OK. It is a skill that I need (Student G, Finland, referring to a picture of a handcraft class).

Interestingly, this was the category that showed the most similarities in the way both groups of students think and express themselves. The notion of time being associated with learning processes reveals what exists beyond the particular culture of each group, a common aspect of student identity. This identity is constructed following a reference to the new content and of a school that prepares students for the future. This final set of results contributes to a broader expression of students' perspectives on learning at school. If the initial set of results opened reflection about students' representation profiles, this last set allowed access to very specific elements that shed light on how students identify, understand, and feel about learning in school.

\section{Discussion}

The starting point of this study was that school, as a learning environment, always is culturally negotiated in everyday practices among teachers, students, and other actors in the school environment. Learning takes place in specific places, including classrooms, with artifacts and objects that hold certain meanings and with particular teachers and peers who produce constraints and affordances for learning (Comber 2016). Moreover, educational settings constitute an embedded system with different layers affecting each other. Differences in how learning is experienced in a specific 
school or class may reflect regional, national, and global politics and economics. In the present study, we explored students' perceptions and experiences with school learning in two contexts - one in Uberlândia, Brazil, and the other in Tampere, Finland. We identified four categories for key learning experiences: actions/practices, materials, interactions with others, and time. Despite the obvious differences (cultural, political, geographical), the two schools appear alike in many ways, and this is reflected in our findings. All the categories were present in the learning experiences of both groups. Hence, it may be argued that these forms are core elements of learning experiences in school.

However, students emphasized core elements in different ways, with qualitative differences inside these elements as perceived by the two student groups. One distinctive difference was in the role of other people in the students' learning experiences. The Finnish students rarely referred to other people in relation to their learning, whereas the Brazilian students viewed teachers and peers as essential parts of the learning process. They saw other people as an emotional and social resource for learning. What stood out in the images and discourse of Finnish students was that the teacher was not present in the descriptions of learning experiences. Students said the teacher gave assignments to them, but that they learned in relation to the learning content. Support from the teacher or peers was not expressed, although giving out assignments could be viewed as instructional support from the teacher.

This particular difference raises questions regarding, e.g., the role of affectivity in teacher-student relations, stated as a universal condition for learning by different researchers over two decades (Dantas 1992; Arantes 2003; Vasconcelos 2004; Ribeiro and Jutras 2006; Franco 2009; Amado et al. 2009). Teachers' affectivity has been indicated as an element that influences motivation, participation, and engagement with studies (Anderson et al. 2004; Klem and Connell 2004; Ribeiro 2008), and in some situations, it supports the idea that motivating students is not a matter of technique, but depends on the relationship established with the subject (Ribeiro 2010). Our findings suggest that we approach social relations in school, particularly feelings of affection between teachers and students, not as universal conditions for learning, but rather as a cultural-contextualized element that can play different roles depending on the social recognition of its importance. We are not understating the importance of affectivity in teacher-student relations, but this study suggests that the meanings applied for such relations can vary significantly and are not identified by all students as a defining element of learning. In any case, we understand that relationships with others are defining how students perceive learning —on one hand, as a socially placed process, and on the other hand, as a more individual and independent activity.

From the other perspective, students in Finland seemed to take responsibility for learning and view learning more as an individual and personal process. Students in the Brazilian group were more inclined to place the responsibility on the teacher and evaluate pedagogical activities from this perspective. Results imply that there are interesting differences in perceptions of what learning is and what it requires. The Brazilian students seemed to recognize social resources around them and put much emphasis on such resources, whereas Finnish students seemed to perceive that they tackled learning challenges by themselves. It is known that the availability and use 
of social support was found to be highly important in successful learning (MurrayHarvey 2010; Upadyaya and Salmela-Aro 2013; Wang and Neihart 2015). On the other hand, taking responsibility for one's own learning has been shown to be crucial for good learning (Hiemstra et al. 2018). It seems that neither of the studied contexts provides an opportunity to construct learning experiences that would both provide support and facilitate ownership of learning.

Moreover, the Finnish group referred to objects of learning, talking explicitly about learning something specific. The Brazilian group referred to learning more as learning to participate in a school's social context. They described learning as part of the social process going on in school and did not seem to have a clear vision of academic content. In other words, based on our findings, the goal of school learning was perceived in different ways in two different student contexts. This is noteworthy; thus, the objects of learning strongly regulate learning processes. Goal-setting is a crucial part of becoming self-regulated in terms of learning (e.g., Zimmerman, 2002). It directs students' attention toward very different aspects in the learning environment and process, leading to a very different kind of knowledge construction and action strategies, resulting in different abilities and competencies and even life strategies. For example, students may concentrate only on bits of knowledge and ignore social elements and processes in the learning environment that could widen their cultural perspectives and offer opportunities to develop social skills. Or else, students' knowledge construction may be based solely on immediate social interactions, allowing situational relations to affect too much of what is considered relevant or true. Both of these strategies may elicit fragmented and incoherent learning. By listening to students' voices in this study, we also learned that learning is associated with the idea of the future, and that there is trust that the content presented to students in school will be important in their future endeavors.

In sum, it seems that despite the common core, the anatomy of learning experiences is very different in distinct cultural contexts, and the difference could be described as subject-related content learning (Finnish group) versus socially embedded emotional learning (Brazilian group). There are probably numerous reasons for these differences. For example, school curricula and local cultural features naturally affect learning experiences. We know much about how educational policy affects schools' resources and students' outcomes. Differences and variations are not bad things per se, but overly narrow or one-sided strategies adopted in school may hinder learning in the future. Moreover, there is the question of what kind of learning we recognize, value, and need in future society globally. To build learning environments that foster equality in society, every school should strive to enable meaningful, adaptive, and coherent learning experiences for students.

\section{Limitations and conclusions}

\subsection{Limitations of the study}

While this study makes contributions to the understanding of how students perceive their learning experiences in school, certain limitations need to be 
recognized. The number of participants in this study is insufficient for establishing representativeness of educational realities in both countries. Rather, we emphasize that as an exploratory investigative process, the study revealed interesting and important aspects of how students construct meaning out of their learning processes, opening the discussion to broader research prospects. It is important to mention that in the Finnish context, there were explicit recommendations to avoid taking photos of other students at school. This orientation could create a sense of privacy that somehow constrained the study, discouraging participants from expressing themselves pictorially. We attempted to overcome this limitation by addressing the students verbally during the focus groups, where there were no recommendations regarding speaking about others in learning situations.

\subsection{Conclusions and future research}

We support extant studies that have pointed out the importance of listening and considering students' perceptions to understand learning processes in school (Gallo 2014; Tsai 2009). Our research suggests that students' perceptions of their own learning processes in school can add to the discussion about the development of pedagogical practices, making them more complex and nuanced while also tempering how we position students through the discourse we are using to describe the problem. What students' perceptions revealed, particularly through the two groups, was that students can identify, analyze, and reflect school learning situations, and by this reflection, they can point very clearly toward which practices should be developed. To this end, and dovetailing with Grover (2004), it is essential to offer opportunities and space for students to define themselves and use their language to describe their experiences. This study reminds us why students should be considered capable stakeholders whose opinions are important and should be taken seriously, as they can significantly contribute to social and pedagogical dialogues designed to influence their lives if we provide them with this opportunity.

In the future, it would be interesting to see more research that can track the impact of macro-level decisions on individual students' learning experiences. Likewise, for further studies, we suggest that children's perspectives be recognized as complementary to perspectives offered by adults and their partial knowledge. In that sense, future research should consider exploring situations in which it is possible to create a juxtaposition between children's and adults' perspectives, investigating how adults can be responsive to the possibilities of change based on children's contributions (Green and Hill 2005).

\section{Compliance with ethical standards}

Conflict of interest The authors declare that they have no conflict of interest. 
Open Access This article is distributed under the terms of the Creative Commons Attribution 4.0 International License (http://creativecommons.org/licenses/by/4.0/), which permits unrestricted use, distribution, and reproduction in any medium, provided you give appropriate credit to the original author(s) and the source, provide a link to the Creative Commons license, and indicate if changes were made.

\section{References}

Aho, E., Pitkänen, K., \& Sahlberg, P. (2006). Policy development and reform principles of basic and secondary education in Finland since 1968. Washington, DC: World Bank, Education Working Paper Series 2.

Allen, Q. (2012). Photographs and stories: Ethics, benefits and dilemmas of using participant photography with Black middle-class male youth. Qualitative Research, 12(4), 443-458.

Amado, J., Freire, I., Carvalho, E., \& Andre, M. J. (2009). O lugar da afetividade na relação pedagógica: contributos para a formação de professores [The space for affectivity in education: contributions for teacher education]. Revista de Ciências da Educação, 8, 75-86.

Anderson, A. R., Christenson, S. L., Sinclair, M. F., \& Lehr, C. A. (2004). Check \& connect: The importance of relationships for promoting engagement with school. Journal of School Psychology, 42(2), 95-113.

Arantes, V. A. (2003). Afetividade e Cognição: Rompendo a Dicotomia na educação [Affectivity and cognition: Overcoming the dichotomy in education]. In M. K. Oliveira, D. Trento, \& T. Rego (Eds.), Psicologia, Educação e as Temáticas da Vida Contemporânea (pp. 23-36). São Paulo: Moderna.

Arias, O., Yamada, G., \& Tejerina, L. (2004). Education, family background and racial earnings inequality in Brazil. International Journal of Manpower, 25(3-4), 355-374.

Azevedo, J. M. L., \& Santos, A. L. F. (2012). Influências do poder central no planejamento da educação dos municípios da região metropolitana do Recife [Influence of central power in the planning of education]. Educação \& Sociedade, 33(119), 551-573.

Bezmer, J., \& Kress, G. (2016). Multimodality, learning and communication. A social semiotic frame (pp. 23-36). London \& New York: Routledge.

Boulton, M. J., Don, J., \& Boulton, L. (2011). Predicting children's liking of school from their peer relationships. Social Psychology of Education, 14, 489-501.

Cano, F., \& Cardelle-Elawar, M. (2004). An integrated analysis of secondary school students' conceptions and beliefs about learning. European Journal of Psychology of Education, 19(2), 167-187.

Clark, A. (2005). Listening to and involving young children: A review of research and practice. Early Child Development and Care, 175(6), 489-505.

Comber, B. (2016). Literacy, place, and pedagogies of possibility. New York and London: Routledge.

Cook, T., \& Hess, E. (2007). What the camera sees and from whose perspectives: Fun methodologies for engaging children in enlightening adults. Childhood, 14, 29-45.

Cowen, R. (2000). Comparing futures or comparing pasts? Comparative Education, 36(3), 333-342.

Dantas, H. (1992). A Afetividade e a Construção do Sujeito na Psicogenética de Wallon [The affectivity and the construction of the individual in Wallon's psychogenetic]. In Y. La Taille (Ed.), Piaget, Vygotsky, Wallon: Teorias Psicogenéticas em Discussão (pp. 75-98). São Paulo: Summus.

de Lima, M. E. C., Geraldi, C. M. G., \& Geraldi, J. W. (2015). O Trabalho com narrativas na investigação em educação [Narratives in educational research]. Educação em Revista, 31(1), 17-44.

Domingo, M. G., \& Garganté, A. B. (2016). Exploring the use of educational technology in primary education: Teachers' perception of mobile technology learning impacts and applications' use in the classroom. Computers in Human Behavior, 56, 21-28.

Eccles, J. S., \& Roeser, R. W. (2011). Schools as developmental contexts during adolescence. Journal of Research on Adolescence, 21(1), 225-241.

Einarsdottir, J. (2005). Playschool in pictures: Children's photographs as a research method. Early Child Development and Care, 175(6), 523-541.

Farley, J. E. (2002). Contesting our everyday work lives: The retention of minority and working-class sociology undergraduates. Sociological Quarterly, 43(1), 1-25. 
Ferreira, J. M., Karila, K., Muniz, L., Amaral, P., \& Kupiainen, R. (2018). Children's perspectives on their learning in school spaces: What can we learn from children in Brazil and Finland? International journal of early childhood, 50(3), 259-277.

Franco, A. F. (2009). O mito da autoestima na aprendizagem escolar [The myth of self-esteem in school learning]. Psicologia Escolar e Educacional, 13(2), 325-332.

Furrer, C., \& Skinner, E. (2003). Sense of relatedness as a factor in children's academic engagement and performance. Journal of Educational Psychology, 95(1), 148.

Gallo, L. E. (2014). Expresiones de lo sensible: Lecturas en clave pedagógica. Educação e Pesquisa, 40(1), 197-214.

Gasser, L., Grütter, J., Buholzer, A., \& Wettstein, A. (2018). Emotionally supportive classroom interactions and students' perceptions of their teachers as caring and just. Learning and Instruction, 54, 82-92.

Gloria, A. M., \& Ho, T. A. (2003). Environmental, social, and psychological experiences of Asian American undergraduates: Examining issues of academic persistence. Journal of Counseling and Development, 81, 93-105.

González-Rey, F. (2002). Qualitative research in psychology: Paths and challenges. São Paulo: Pioneira Thompson Learning.

González-Rey, F., \& Mitjánz, A. (2015). Una epistemología para el estudio de la subjetividad: Sus implicaciones metodológicas [An epistemology to study subjectivity: its methodological implications]. Psicoperspectivas, 15(1), 5-16.

Green, S., \& Hill, M. (2005). Researching children's experience: Methods and methodological issues. In S. Green \& D. Hogan (Eds.), Research children's experience: Approaches and methods (pp. 1-21). London: Sage Publications.

Greeno, J. G. (1997). Response: On claims that answer the wrong question. Educational Researcher, 20(1), 5-17.

Grover, S. (2004). Why won't they listen to us? On giving power and voice to children participating in social research. Childhood, 11(1), 81-93.

Hakkarainen, K., Palonen, T., Paavola, S., \& Lehtinen, E. (2004). Communities of networked expertise: Professional and educational perspectives. Amsterdam: Elsevier.

Hanks, W. F. (1991). Foreword. In J. Lave \& E. Wenger (Eds.), Situated learning. Legitimate peripheral participation (pp. 13-23). Cambridge: Cambridge University Press.

Hanson, K. (2012). Schools of thought in children's rights. In M. Liebel (Ed.), Children's rights from below: Cross-cultural perspectives (pp. 61-79). New York, NY: Palgrave MacMillan.

Harcourt, D., \& Mazzoni, V. (2012). Standpoints on quality: Listening to children in Verona, Italy. Australasian Journal of Early Childhood, 37(2), 19-26.

Harper, D. (2002). Talking about pictures: A case for photo elicitation. Visual Studies, 17(1), 13-26.

Henderson, M., Selwyn, N., \& Aston, R. (2017). What works and why? Student perceptions of "useful" digital technology in university teaching and learning. Studies in Higher Education, 42(8), $1567-1579$.

Hiemstra, D., Yperen, N. W. V., \& Timmerman, M. E. (2018). Students' effort allocation to their perceived strengths and weaknesses: The moderating effect of instructional strategy. Learning and Instruction. https://doi.org/10.1016/j.learninstruc.2018.01.003.

Kauko, J., Centeno, V. G., Candido, H., Shiroma, E., \& Klutas, A. (2016). The emergence of quality assessment in Brazilian basic education. European Educational Research Journal, 15(5), 558-579.

Klem, A. M., \& Connell, J. P. (2004). Relationships matter: Linking teacher support to student engagement and achievement. Journal of School Health, 74(7), 262-273.

Kondracki, N. L., Wellman, N. S., \& Amundson, D. R. (2002). Content analysis: Review of methods and their applications in nutrition education. Journal of Nutrition Education Behavior, 34(4), 224-230.

Krapp, A. (2005). Basic needs and the development of interest and intrinsic motivational orientations. Learning and Instruction, 15(5), 381-395.

Kupiainen, R. (2013). Media and digital literacies in secondary school. New York: Peter Lang.

Larrosa, J. (2002). Notas sobre a experiência e o saber de experiência [Notes of the experience and the knowledge from experiênce]. Revista Brasileira de Educacão, 19, 20-28.

Lasky, S. (2005). A sociocultural approach to understanding teacher identity, agency and professional vulnerability in a context of secondary school reform. Teaching and Teacher Education, 21(8), 899-916.

Lee, J. (2012). The effects of the teacher-student relationship and academic press on student engagement and academic performance. International Journal of Educational Research, 53, 330-340. 
Lonka, K., Hakkarainen, K., \& Sintonen, M. (2000). Progressive inquiry learning for children-Experiences, possibilities, limitations. European Early Childhood Education Research Journal, 8(1), 7-23.

Magen-Nagar, N., \& Steinberger, P. (2017). Characteristics of an innovative learning environment according to students' perceptions: Actual vs preferred. Learning Environments Research, 20(3), 307-323.

Martin, A. J., \& Dowson, M. (2009). Interpersonal relationships, motivation, engagement, and achievement: Yields for theory, current issues, and educational practice. Review of Educational Research, 79(1), 327-365.

Massey, D. (2010). For space. Thousand Oaks, CA: Sage.

Morin, E. (1990). Introduccion al pensamiento complejo [Introduction to Complex Thinking]. Madrid: Gesida.

Murray-Harvey, R. (2010). Relationship influences on students' academic achievement, psychological health, and well-being at school. Educational \& Child Psychology, 27(1), 104-115.

Newman, F., \& Holzman, L. (1993). Lev Vygotsky: Revolutionary scientist. London: Routledge.

Niekerk, M. P. V. (2015). Student's perception on IWB through the lenses of the community of inquiry framework. South African Journal of Education, 35(4), 1-10.

Nonaka, I., \& Nishiguchi, T. (Eds.). (2001). Knowledge emergence: Social, technical and evolutionary dimensions of knowledge creation. Oxford: Oxford University Press.

Paavola, S., \& Hakkarainen, K. (2005). The knowledge creation metaphor: An emergent epistemological approach to learning. Science \& Education, 14(6), 535-557.

Patrick, H., Ryan, A. M., \& Kaplan, A. (2007). Early adolescents' perceptions of the classroom social environment, motivational beliefs, and engagement. Journal of Educational Psychology, 99(1), 83-98.

Pyhältö, K., Soini, T., \& Pietarinen, J. (2010). Pupils' pedagogical well-being in comprehensive school: Significant positive and negative school experiences of Finnish ninth graders. European Journal of Psychology of Education, 24, 447-463.

Quin, D., Hemphill, S. A., \& Heerde, J. A. (2017). Associations between teaching quality and secondary students' behavioral, emotional and cognitive engagement in school. Social Psychology of Education, 20(4), 807-829.

Resnick, L. B. (1991). Shared cognition: Thinking as social practice. In L. B. Resnick, J. M. Levine, \& S. D. Teasley (Eds.), Perspectives on socially shared cognition (pp. 1-20). Washington, DC: American Psychological Association.

Ribeiro, M. L. (2008). A afetividade no bojo dos currículos deformação de professores [Affectivity within the curriculum of teacher education]. In Conference proceeding $14^{\circ}$ Encontro Nacional de Prática de Ensino, Porto Alegre, RS.

Ribeiro, M. L. (2010). A afetividade na relação educativa [Affectivity in the teaching relationship]. Estudos de Psicologia., 27(3), 403-412.

Ribeiro, M. L., \& Jutras, F. (2006). Representações sociais de professores sobre afetividade [Teachers' social representations of affectivity]. Estudos de Psicologia, 23(1), 39-45.

Rutanen, N., Amorim, K. S., Colus, K., \& Piattovena, N. (2013). What is best for the child? Early childhood education and care for children under 3 years of Age in Brazil and in Finland. International Journal of Early Childhood, 45, 1-21.

Rutanen, N., Costa, C., \& Amorim, K. S. (2016). Instructional strategies, discipline and children's participation in educational institutions for children under three-years-old: Cases from Brazil and Finland. International Journal of Humanities and Social Science Center for Promoting Ideas, 6 , 204-215.

Sahlberg, P. (2011a). Finnish lessons: What can the world learn from educational change in Finland?. New York: Teachers College Press.

Sahlberg, P. (2011b). The fourth way of Finland. Journal of Educational Change, 12(2), 173-185.

Salomon, G., \& Perkins, D. N. (1998). Individual and social aspects of learning. Review of Research in Education, 23, 1-24.

Schenke, K., Ruzek, E., Lam, A. C., Karabenick, S. A., \& Eccles, J. S. (2017). Heterogeneity of student perception of the classroom climate: a latent profile approach. Learning and Environment Research, 20(3), 289-306.

Schleicher, A. (Ed.). (2012). Preparing teachers and developing school leaders for the 21st century lessons from around the world. Paris: OECD Publishing.

Schoenfeld, A. H. (1999). Looking toward the 21st century: Challenges of educational theory and practice. Educational Researcher, 28(7), 4-14. 
Sfard, A. (1998). On two metaphors for learning and the dangers of choosing just one. Educational Researcher, 27(2), 4-13.

Shiroma, E., \& Schneider, M. C. (2012). Avaliação do desempenho docente: contradições da política para poucos na era do para todos. Inter-ação, 38(1), 8-107.

Simola, H. (2005). The Finnish miracle of PISA: Historical and sociological remarks on teaching and teacher education. Comparative Education, 41(4), 455-470.

Soja, E. W. (2011). Preface. In K. M. Leander \& M. Sheehy (Eds.), Spatializing literacy research and practice (pp. 9-15). New York: Peter Lang.

Telles, J. A. (2006). Pesquisa Educacional com base nas artes: pensando a educação dos professores como experiência estética. Revista Educação e Pesquisa, 32(3), 509-530.

Telles, J. A. (2007). Reflexão deflagrada por fotografias: o discurso justificador e as representações da formação profissional de professores [Reflection elicited by photographs: The justified discourse and the representations of professional teachers]. Revista Linguagem e Ensino, 10(2), 327-370.

Thinker, P. (2013). Using photographs in social and historical research. Los Angeles: Sage Publications.

Tsai, C. (2009). Conceptions of learning science among high school students in Taiwan: A phenomenographic analysis. International Journal of Science Education, 26(4), 733-1750.

Ulmanen, S., Soini, T., Pietarinen, J., \& Pyhältö, K. (2014). Strategies for academic engagement perceived by Finnish sixth- and eighth-graders. Cambridge journal of education, 44(3), 425-443.

Upadyaya, K., \& Salmela-Aro, Katariina. (2013). Development of school engagement in association with academic success and well-being in varying social contexts: A review of empirical research. European Psychologist, 18(2), 136-147.

Valsiner, J. (2000). Culture and human development. Great Britain: Sage.

Vasconcelos, M. S. (2004). Afetividade na escola: alternativas teóricas e práticas [Affectivity in school: Alternative theory and practice]. Educação e Sociedade., 25(87), 616-620.

Vermunt, J. D., \& Vermetten, Y. J. (2004). Patterns in student learning: Relationships between learning strategies, conceptions of learning, and learning orientations. Educational Psychology Review, 16(4), 359-384.

Vygotsky, L. S. (1991). A formação social da mente [Mind and society]. São Paulo: Martins Fontes.

Wallon, H. (1981). A evolução psicológica da criança [The psychological evolution of the child]. Lisbon: Setenta.

Wang, C. W., \& Neihart, M. (2015). How do support from parents, teachers, and peers influence academic achievement of twice-exceptional students? Gifted Child Today, 38(3), 148-159.

Wenger, E. (1998). Communities of practice: Learning, meaning and identity. Cambridge: Cambridge University Press.

Wentzel, K. R. (1999). Social-motivational processes and interpersonal relationships: Implications for understanding motivation at school. Journal of Educational Psychology, 91(1), 76-97.

Wertsch, J., Tulviste, P., \& Hagstrom, F. (1993). A sociocultural approach to agency. In A. Forman, N. Minick, \& A. Stone (Eds.), Context for learning sociocultural dynamics in children's development (pp. 336-357). New York: Oxford University Press.

Woodward, K. (2003). Identidade e diferença: uma introdução teórica e conceitual [Identity and difference: Theoretical and conceptual introduction]. In T. T. da Silva (Ed.), Identidade e diferença: A perspectiva dos estudos culturais (pp. 7-67). Petrópolis: Vozes.

Zimmerman, B. (2002). Becoming a self-regulated learner: An overview. Theory into Practice, 41(2), $64-70$

Publisher's Note Springer Nature remains neutral with regard to jurisdictional claims in published maps and institutional affiliations.

Juliene Madureira Ferreira (Ph.D.) is a full-time postdoctoral researcher at the Faculty of Education and Culture, Tampere University, Finland. Her research interests include inclusive education, special education, learning and development through peer interactions, and more recently the embodied experiences in collaborative learning.

Tiina Soini, (Ph.D.) is research director Faculty of Education and Culture, Tampere University and adjunct professor in Philosophical Faculty, University of Eastern Finland. Soini a research theme leader (childhood) in multidisciplinary research center of Tampere Centre for Childhood, Youth and Family Research 
PERLA. Her research interest include, educational reforms, school development, teachers' professional agency and well-being and pupils learning agency.

Reijo Kupiainen (Ph.D.) is adjunct professor of Media Education at the Department of Education and Lifelong Learning, Faculty of Social and Educational Sciences at the Norwegian University of Science and Technology, Norway, and University Lecturer of Media Education at the Faculty of Education and Culture, Tampere University, Finland. He's research interests include media education, media literacy, visual culture and multiliteracies.

Ana Claudia Salum, (Ph.D.) is adjunct professor of English language at the teacher training school of the Federal University of Uberlândia, Brazil. Her research interests include interpretation as a discursive process, meaning making and subjectivity of students in elementary education and teacher training in English language.

\section{Affiliations}

\section{Juliene Madureira Ferreira ${ }^{1}$ (D) Tiina Soini $^{1} \cdot$ Reijo Kupiainen $^{1,2}$. Ana Claudia Salum ${ }^{3}$}

Tiina Soini

Tiina.soini-ikonen@tuni.fi

Reijo Kupiainen

reijo.p.kupiainen@ntnu.no

Ana Claudia Salum

Ana.Salum@ufu.br

1 Department of Education and Culture, Tampere University, Åkerlundinkatu 5, Virta 509, 33014 Tampere, Finland

2 Faculty of Social and Educational Science, Norwegian University of Science and Technology, Trondheim, Norway

3 Department of Language of the Teacher Training School, Universidade Federal de Uberlândia, Uberlândia, Brazil 